\title{
GREEN FAÇADES: BENEFITS, INDICATORS AND DESIGN PARAMETERS
}

\author{
VALERIA A. MOREIRA-ZAMBRANO ${ }^{1} \&$ DAVID MORENO-RANGEL ${ }^{2}$ \\ ${ }^{1}$ Universidad Laica Eloy Alfaro de Manabí, Ecuador \\ ${ }^{2}$ Instituto Universitario de Arquitectura y Ciencias de la Construcción, Universidad de Sevilla, Spain
}

\begin{abstract}
In the next five years, according to the World Meteorological Organization, the global average temperature will rise between $1.2^{\circ} \mathrm{C}$ and $1.3^{\circ} \mathrm{C}$ above the pre-industrial period. For the United Nations, if we support the latest analysis, we can reduce carbon emissions and stop the increase in the average annual temperature to below $2{ }^{\circ} \mathrm{C}$. The United in Science Report, issued at the Climate Action Summit, showed the importance of developing actions that could stop global warming and the effects of climate change. In the topics exposed, it proposed acting through local and city actions, which allow the mitigation and resilience at the urban and local levels, focused on low-emission buildings and urban infrastructure; where vertical gardens allow carrying out these actions. The green façades not only reduce the effects of global warming, but also help to improve indoor and outdoor comfort. Beyond the aesthetic benefits, they allow the increase of local biodiversity, food production, decrease pollution rates, help acoustic and thermal insulation of internal spaces and benefit energy savings. The objective of this research is to analyze how vertical gardens act in the outdoor areas, comparing the indicators and design parameters that establish the environmental certifications, such as LEED, BREEAM and CASBEE. The methodology for the research is developed in three stages: (i) study of the vertical garden as a mitigating element of the heat island effect and external comfort; (ii) analysis and comparison of environmental certifications, to know what are the indicators and design parameters that they consider for the implementation of green façades; and (iii) quantitative and qualitative benefits of the implementation of green façades in urban environments from the results obtained through a simulation in the ENVI_MET software, applied to a specific case study. According to the analysis based on the simulation performed, the use of these vegetable skins in small percentages (10-20\%) minimally improves exterior comfort.
\end{abstract}

Keywords: green façades, indicators, parameters, LEED, BREEAM, CASBEE, ENVI_MET.

\section{INTRODUCTION}

Recent studies show that the increase in population and economic growth are the main drivers of energy consumption and one of the main causes of $\mathrm{CO}_{2}$ emissions [1]. That is why contemporary architecture has been designed an objective to develop eco-architecture or also known as green construction [2], as a model for the development of the daily activities of individuals in cities, which is based on the design and the implementation of buildings and green spaces [3].

Green infrastructures are shown as a suitable applicable solution, since they can serve for reconstruction or adjustment of the affected infrastructures [4], and even contribute to mitigation and adaptation to climate change thanks to the multifunctionality of green spaces, improving people's quality of life [5]. Green façades integrate naturally into the urban landscape without any visual impact, for the user of the infrastructure or for the inhabitants of the area.

Green façades fulfill different objectives, whether they be ornamentation, food production, physical aspects, naturalization, and others [6]. On the other hand, they have "aesthetic" advantages such as visual sustainability; "Ecological" since they act as a natural filter of the air; "Hygro-thermoacoustic" because the green mattress acts as a highperformance thermal insulation and prevents excessive solar gain. In addition, they help 
regulate the acoustic aspects of the envelope, reducing the reverberation of the wave, avoiding its reflection by up to $50 \%$ compared to conventional screens.

In recent years, different ways and models have been implemented to follow for the sustainable development of cities. The sustainability evaluation and certification systems have developed a series of requirements (green façades, green roofs, urban green, among others) which allow obtaining credits, which certify the constructions as sustainable [2].

Design indicators and parameters for the evaluation process, the limits of restrictions in terms of organization and design, maximum and minimum, assess whether a new or existing project is sustainable. However, these may not be available in different contexts or realities if they are followed with extreme rigor; For this reason, this research seeks to analyze the benefits of one of them: green façades, and establish a comparison of the behavior of the parameters for them in a specific environment, with the aim of knowing which values of the mentioned indicator or design parameters, detected a greater feeling of comfort in the studied area.

\section{METHODOLOGY}

The methodological process of the research is based on the study of basic concepts, theories developed, projects carried out, case studies, simulations, analysis and comparisons of results, conclusions and discussion of the behavior of green walls and their influence on comfort in outdoor spaces. The research has been carried out in three stages where: in the initial part, an approach to the subject is generated starting from the study of the vertical garden as a mitigating element of the heat island effect and external comfort; In addition, environmental certifications and their indicators and design parameters are studied. In the second part, the case study is introduced where the base model is analyzed and compared with respect to the implementation of green façades in outdoor spaces according to CASBEE (green walls: $10 \%$ and $20 \%$ ), to finally know the quantitative and qualitative benefits obtained from the presence of vertical gardens according to the results achieved in the case study carried out.

\section{GREEN FAÇADES IN EXTERIOR SPACES}

The green façades or green walls developed by the French botanist Patrick Blanc, consist of a vertical hydroponic cultivation system. According to Blanc [7], this system is based on the ability of many plants to develop epiphytic growth, growing on the surface of rocks, other plants, or other objects.

The implementation of green façades, for the most part, is usually complemented using green roofs, with the general objective of achieving more ecologically sustainable urban planning [8].

Among the most important benefits of green façades in outer space, we can mention:

1. Improvement of air quality [9].

2. Passive air conditioning of buildings by retaining solar radiation [8].

3. Increase in biodiversity [10], as well as the appearance of new alternatives for urban agriculture, since it allows the production of vegetables, fruits, and various species of interest.

4. Emergence of opportunities for technological, economic and employment development for urban dwellers [11].

5. Reduction of the "heat island" effect, since an evapotranspiration is generated on the green façade [12]. 


\subsection{Heat island effect}

Climate is made up of elements or variables that characterize it in two ways: spatial or temporal. Throughout the city, climatic conditions are modified, so a characteristic microclimate of urban areas appears, the same one that is identified according to the variations in climatic parameters [13].

The heat island is a phenomenon that affects the urban microclimate. During the day, the solid surface of the city appears thermally cooler than the surrounding countryside, so it emits less heat than this [14]. However, this increases the air temperature proportionally to the density and size of the city (urban canyons) [15]. Among other aspects, the high absorption of materials present in the city, the scarcity of green spaces, the morphological characteristics of urban canyons, and the anthropogenic heat released also influence, as well as solar radiation, wind, water, among others. The heat island effect can cause inadequate levels of air quality with effects on human health.

\subsection{Environmental certifications}

Environmental assessment systems, indicators and modeling are extremely important tools that are being developed to diagnose the current state and its possible behavior of buildings and urban areas [16]. Environmental assessment systems are voluntary instruments to measure and compare the contribution of a building and/or urbanization to sustainability. These are characterized by evaluating the environmental performance of a building or urbanization, giving it a final overall rating or score. To do this, they establish a series of indicators or parameters. The final grade is the direct sum of the partial scores obtained or the weighted sum, this allows comparing the results obtained by different buildings and/or housing developments. Over the years, countless environmental certifications have been created around the world.

For the development of this research, indicators and design parameters proposed by LEED, BREEAM and CASBEE, that seek to improve the habitability conditions of the neighborhoods through the implementation of green façades have been studied. Which, after an analysis was decided to work with indicators and design parameters proposed by CASBEE, since the context in which they will carry out the study, can be adapted to these changes. Table 1 shows the indicators and parameters to consider in the research.

Table 1: Indicators and design parameters.

\begin{tabular}{|l|l|l|}
\hline Indicator & Reference values & Organization \\
\hline Green walls & $\begin{array}{l}10-20 \% \text { of the walls } 10 \mathrm{~m} \text { (vertical) } \\
\text { from the pedestrian }\end{array}$ & CASBEE \\
\hline
\end{tabular}

\section{CASE STUDY: PORTOVIEJO, MANABÍ, ECUADOR}

Portoviejo is located in the province of Manabí in Ecuador. In recent years, the city has undergone a series of transformations, the latest of these, a cause of an earthquake that affected the most vulnerable areas of the city, including the historic center. Culturally and socially, the historic center has been a landmark, being part of the daily life of the Portoviejo's people, being the most important commercial point of the city. Because of this catastrophe (4 years later), the center has not been fully rehabilitated, leaving without intervention one of the most isolated areas, known as the heart of the city. For the case study, simulations of the 


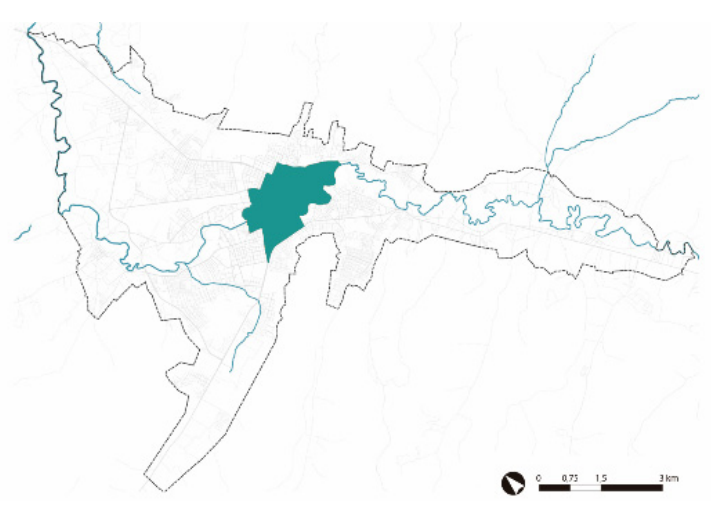

Figure 1: Study area location, District 9.

current state of a part of the historic center, currently known as District 9, will be carried out, where 12 blocks were chosen, which were reinterpreted, to be the simulate base model (Fig. 1).

For the research, the following simulation platform has been chosen: ENVI_MET. ENVI_MET has been subject to validation and verification by different authors since it has been used in a series of urban projects, research projects, studies and doctoral theses throughout the last two decades (Bruse et al. [17], Alcazar [18]). These works have developed validation models that verify the reliability of the tool to reproduce microclimatic phenomena and especially the impact of vegetation.

The ENVI_MET model of 1D limits generates one-dimensional profiles for meteorological parameters such as air temperature, specific humidity, and wind vectors (horizontal) for each vertical profile [19]. The size of the model areas largely depends on the spatial resolution of the model. To perform the simulations, the extension of the total model area was thought to fit the extension of the basic ENVI_MET model grid.

For this, the simulation grid was $35 \times 35$ cells horizontally and 29 cells vertically, with a cell size of $10 \times 10 \times 1$. The total simulated area was $1225 \mathrm{~m}^{2}$ and the analysis is made at a height of $1.50 \mathrm{~m}$ (Fig. 2). This resolution allows to analyze the interactions on a general scale and between buildings, surfaces, and individual plants for the different scenarios in a period of 24 hours.

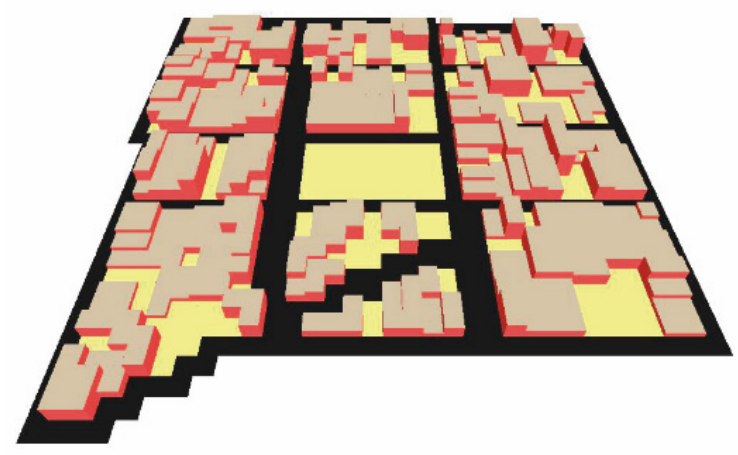

Figure 2: 3D view, base model. (Source: Obtained from ENVI_MET.) 
For the case study three simulations will be used: base model, green façades $10 \%$ and green façades $20 \%$.

\section{RESULTS}

\subsection{Base model simulation}

The base model (BM) has been simulated in the ENVI_MET software in its Beta version. This has been simulated on four different dates in 2018. On the equinoxes 20 March and 22 September and on the solstices 21 June and 21 December, where it seeks to analyze the current behavior of the plot, in two different specific schedules during the day: 13:00 and 16:00.

From the base model simulations, data on air temperature, wind speed, relative humidity, $\mathrm{CO}_{2}$ ppm and PMV have been obtained, where its current behavior can be observed.

Thermal comfort is an indicator defined by the American Society of Heating, Refrigerating and Air-Conditioning Engineers (ASHRAE), as that condition in which satisfaction with the thermal environment is expressed where there is a balance between the psychic and physiological sensations of the human being and his immediate environment [20]. For this, it has been considered to analyze three specific areas of the plot to evaluate their behavior: Urban void, Street 1 and Street 2 (Fig. 3).
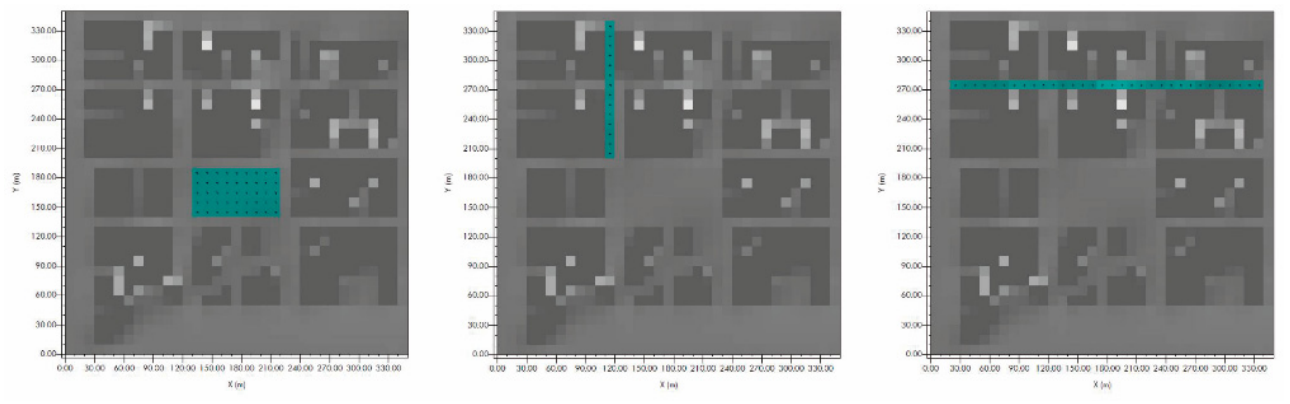

Figure 3: Base model: Urban void, Street 1 and Street 2. (Source: Obtained from ENVI_MET.)

5.1.1 Base model analysis

To analyze the behavior of the analyzed spaces, the median of the items studied has been obtained (Table 2).

Table 2: Summary of general base model values: Urban void, Street 1 and Street 2.

\begin{tabular}{|l|c|c|c|c|c|}
\hline Median & $\begin{array}{c}\text { Air temperature } \\
\left({ }^{\circ} \mathrm{C}\right)\end{array}$ & $\begin{array}{c}\text { Relative humidity } \\
(\%)\end{array}$ & $\begin{array}{c}\text { Wind speed } \\
(\mathrm{m} / \mathrm{s})\end{array}$ & $\mathrm{CO}_{2}$ & $\mathrm{PMV}$ \\
\hline Urban void & 24.6 & 74.3 & 0.5 & 400.8 & 0.2 \\
\hline Street 1 & 25.3 & 70.9 & 0.4 & 401.5 & 0.3 \\
\hline Street 2 & 25.0 & 72.2 & 0.7 & 401.6 & 0.4 \\
\hline
\end{tabular}


For the base model analysis, it can be concluded that the values that most influence the comfort of a space are: air temperature and relative humidity, with temperature being the most determining value, where:

1. If the air temperature is optimal, a despite the relative humidity is high and the space has an average wind speed, the values of $\mathrm{CO}_{2}$ and PMV will be good, compared to the remaining spaces.

2. If the air temperature is high, even though the relative humidity is low and the space has a low wind speed, the $\mathrm{CO}_{2}$ and PMV values will be average, compared to the remaining spaces.

3. If the air temperature and relative humidity are medium and the space has a high wind speed, the $\mathrm{CO}_{2}$ and PMV values will be high, compared to the remaining spaces.

\subsection{Simulation of the green façades: $10 \%$ and $20 \%$ (Fig. 4)}

The green façade model: $10 \%$, has been simulated on four different dates in 2018 . On the equinoxes 20 March and 22 September and on the solstices 21 June and 21 December, at two different times during the day: 1:00 p.m. and 4:00 p.m. The height considered for the simulations is $1.50 \mathrm{~m}$ high (relating it to the human scale), in the simulation the values of: air temperature, relative humidity, air speed, $\mathrm{CO}_{2}$ and $\mathrm{PMV}$ have been extracted; where, to define the thermal comfort ranges, the values of the bicyclical charts of Olgyay, Givoni and the Physiological Adaptation Model-UTCI have been considered for the values of air temperature, relative humidity and wind speed, in the same way that in the base model, as well as ISO 7730-Determination of the Expected Average Vote-PMV and the expected percentage of dissatisfied people-PPD, indices and specifications of the thermal comfort conditions, for the PMV values and, for the general values of $\mathrm{CO}_{2}$, those stipulated by González and González [21].
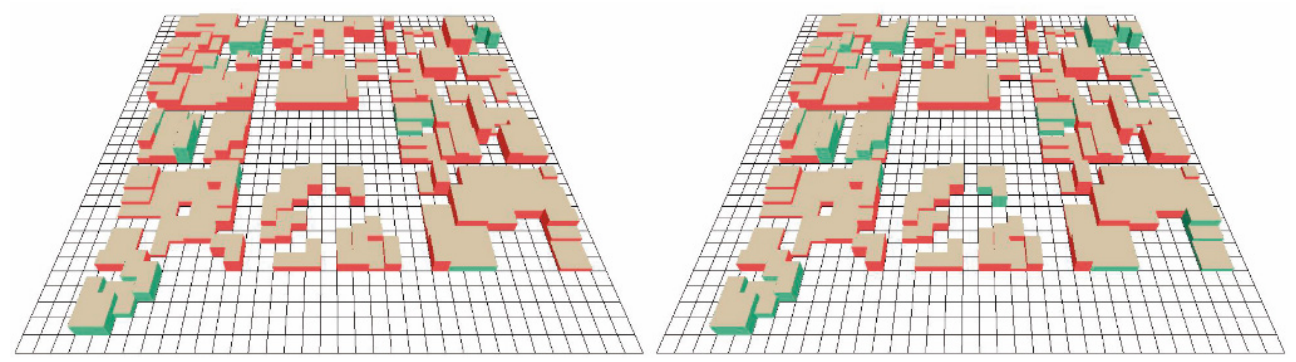

Figure 4: Green façade model: 10\% and 20\%. (Source: Obtained from ENVI_MET.)

Table 3: Summary of general values of the green façade model. 10\%: Urban void, Street 1 and Street 2.

\begin{tabular}{|l|c|c|c|c|c|}
\hline Median & $\begin{array}{c}\text { Air temperature } \\
\left({ }^{\circ} \mathrm{C}\right)\end{array}$ & $\begin{array}{c}\text { Relative humidity } \\
(\%)\end{array}$ & $\begin{array}{c}\text { Wind speed } \\
(\mathrm{m} / \mathrm{s})\end{array}$ & $\mathrm{CO}_{2}$ & $\mathrm{PMV}$ \\
\hline Urban void & 24.7 & 74.3 & 0.5 & 400.8 & 0.3 \\
\hline Street 1 & 25.2 & 71.4 & 0.4 & 401.9 & 0.4 \\
\hline Street 2 & 25.3 & 68.8 & 0.6 & 401.7 & 0.5 \\
\hline
\end{tabular}


5.2.1 Green façade model analysis: $10 \%$.

To analyze the behavior of the analyzed spaces, the median of the analyzed items has been obtained (Table 3 ).

For the green façade model analysis: $10 \%$, it can be concluded that:

1. Urban void with the green façade presence: $10 \%$, compared to the base model: it is the most thermally comfortable despite suffering an increase, which also affects PMV; however, it is still the space that is closest to the neutral zone according to the ISO 7730 standard. In addition, it has the highest percentages of relative humidity compared to the remaining spaces. Its wind speed values are maintained compared to the base model and it is still the one that produces less $\mathrm{CO}_{2}$.

2. Street 1 with the green façade presence: $10 \%$ compared to the base model: it suffers an increase in its relative humidity percentage values, and this affects that it stops being the most comfortable in this aspect. However, the temperature decreases relative to the base model. In addition, the values of $\mathrm{CO}_{2}$ and PMV emissions are increased in respect of the base model, and the speed does not change regarding to the base model.

3. Street 2 with the green façade presence: $10 \%$, compared to the base model: it continues to be the space with the highest wind speed, despite decreasing according to the base model. However, the temperature undergoes an increase which makes the space become the one with the highest temperature. In addition, it suffers an increase in $\mathrm{CO}_{2}$ and PMV emissions compared to the base model. It also lowers its relative humidity values considerably compared to the base model.

5.2.2 Green façade model analysis: $20 \%$.

To analyze the behavior of the analyzed spaces, the median of the analyzed items has been obtained (Table 4).

Table 4: Summary of general values of the green façade model: 20\%: Urban void, Street 1 and Street 2.

\begin{tabular}{|l|c|c|c|c|c|}
\hline Median & $\begin{array}{c}\text { Air temperature } \\
\left({ }^{\circ} \mathrm{C}\right)\end{array}$ & $\begin{array}{c}\text { Relative humidity } \\
(\%)\end{array}$ & $\begin{array}{c}\text { Wind speed } \\
(\mathrm{m} / \mathrm{s})\end{array}$ & $\mathrm{CO}_{2}$ & $\mathrm{PMV}$ \\
\hline Urban void & 24.6 & 74.1 & 0.5 & 400.9 & 0.3 \\
\hline Street 1 & 25.3 & 71.3 & 0.3 & 401.6 & 0.4 \\
\hline Street 2 & 25.2 & 69.1 & 0.7 & 401.7 & 0.5 \\
\hline
\end{tabular}

For the green façade model analysis: $20 \%$, it can be concluded that:

1. Urban void with green façade presence: $20 \%$, compared to the base model: it is the most thermally comfortable, its values remain regarding to the base model. Despite suffering an increase in the PMV, it is still the space that is closest to the neutral area according to the ISO 7730 standard. In addition, it has the highest percentages of relative humidity, despite decreasing in this case compared to the base model. Its wind speed values are maintained and it is still the one that produces the least $\mathrm{CO}_{2}$ despite suffering an increase compared to the base model.

2. Street 1 with green Façade presence: $20 \%$, compared to the base model: it suffers an increase in its relative humidity percentage values. However, in terms of temperature, these values are maintained. In addition, the values of $\mathrm{CO}_{2}$ and $\mathrm{PMV}$ emissions increase compared to the base model, and the speed decreases. 
3. Street 2 with green façade presence: $20 \%$, compared to the base model: it continues to be the space with the highest wind speed; however, the temperature undergoes an increase compared to the base model. In addition, it suffers an increase in $\mathrm{CO}_{2}$ and PMV emissions in respect of the base model, and its relative humidity values decrease considerably regarding to the base model, making it the most comfortable space, in terms of humidity, in this case.

\section{COMPARISON}

For the analysis of the green wall models, a comparative analysis was carried out based on increases in the green wall model $10 \%$ and the green wall model $20 \%$ compared to the base model, where it is observed that:

1. In air temperature, after obtaining the medians of the analyzed areas and comparing them with each other, it can be seen that the $20 \%$ green wall model is the most beneficial compared to the base model, obtaining a final median of $25.1^{\circ} \mathrm{C}$, while for the base model it reaches $25^{\circ} \mathrm{C}$ and the green wall model $10 \%$ remains at $25.2^{\circ} \mathrm{C}$.

2. In relative humidity, after obtaining the medians of the analyzed areas and comparing them with each other, it can be seen that the $20 \%$ green wall model is the most beneficial compared to the base model, obtaining a final median of $71.3 \%$, while for the base model it reaches $72.2 \%$ and the green wall model $10 \%$ reaches $71.4 \%$.

3. In the wind speed, after obtaining the medians of the analyzed areas and comparing them with each other, it can be seen that the $10 \%$ green wall model is the most beneficial compared to the base model, obtaining a final median of $0.50 \mathrm{~m} / \mathrm{s}$, while for the BM it reaches $0.50 \mathrm{~m} / \mathrm{s}$ and the $20 \%$ green wall model reaches $0.55 \mathrm{~m} / \mathrm{s}$.

4. In $\mathrm{CO}_{2}$, after obtaining the medians of the analyzed areas and comparing them with each other, it can be seen that the $20 \%$ green wall model is the most beneficial compared to the base model, obtaining a final median of $401.5 \mathrm{ppm}$, while for the base model reaches $401.6 \mathrm{ppm}$ and the $10 \%$ green wall model reaches $401.7 \mathrm{ppm}$.

5. In PMV, after obtaining the medians of the analyzed areas and comparing them with each other, it can be seen that the $10 \%$ green wall model is the most beneficial compared to the base model, obtaining a final median of $0.3 \mathrm{pmv}$, while for the base model reaches $0.35 \mathrm{pmv}$ and the $20 \%$ green wall model reaches $0.4 \mathrm{pmv}$.

In addition, some charts have been made where there is seen the analyzed areas (Urban void, Street 1 and Street 2), and their approach to comfort, in terms of air temperature and relative humidity. Figs 5-7 are based on the comfort ranges studied for this research.

\section{CONCLUSIONS}

Based on the results of the investigation, it can be concluded that:

1. Green walls are elements that help the interior thermal comfort of buildings. However, in public spaces, these helps improve comfort. In the case of the simulated plot, the green wall helps to improve the relative humidity of the spaces, as well as the value of $\mathrm{CO}_{2}$ and PMV emissions.

2. It is important to clarify that, with the implementation of the green wall in buildings, the values do not improve in large quantities, this improvement is minimal. Green façades have little impact on the comfort of public space for this case. However, it is proven that they help the internal comfort of buildings. If the research were based on interior comfort, surely the green wall would greatly help these interior spaces. 


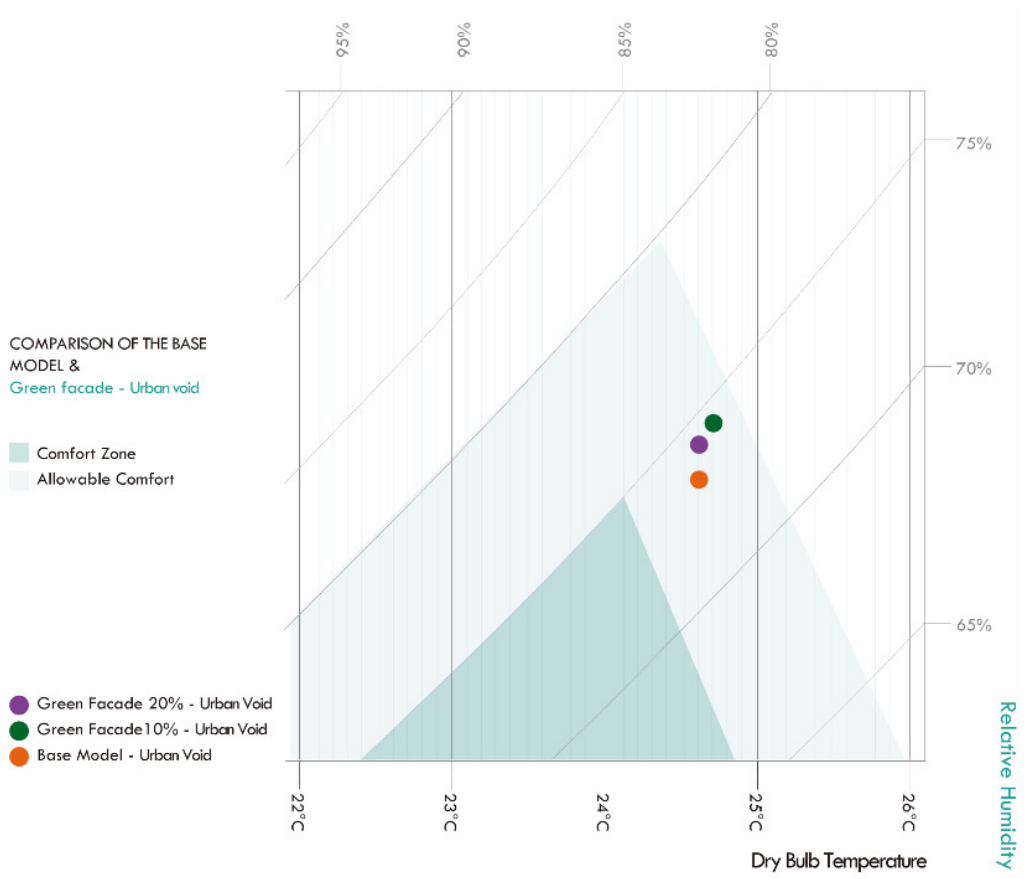

Figure 5: Comparison of the base model and green façades 10\% and 20\% - Urban void.

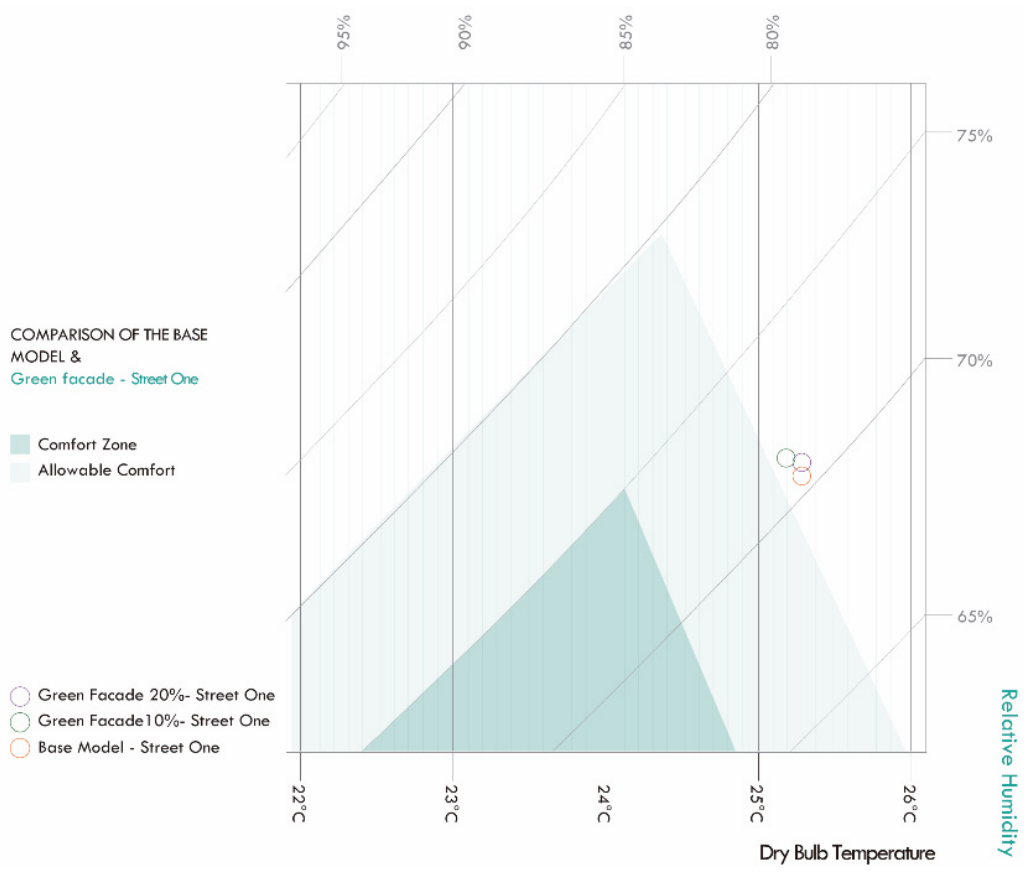

Figure 6: Comparison of the base model and green façades $10 \%$ and 20\% - Street 1 . 


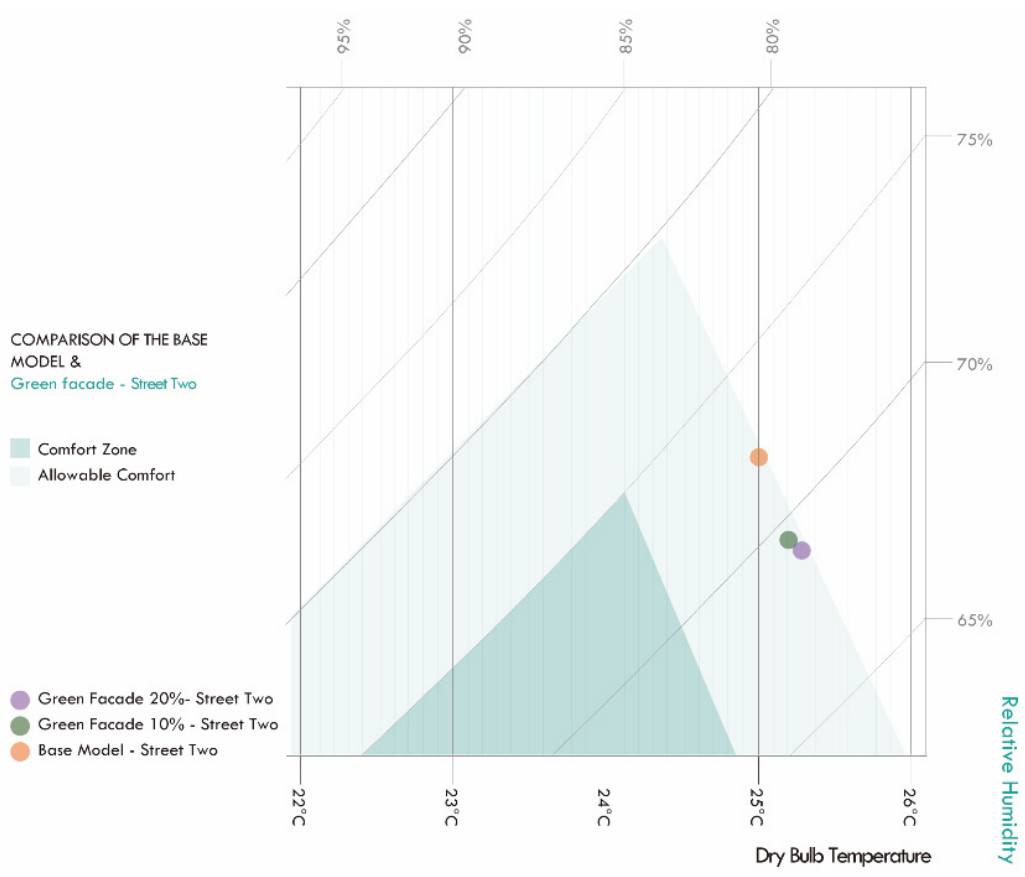

Figure 7: Comparison of the base model and green façades $10 \%$ and $20 \%$ - Street 2 .

3. The urban void is the most comfortable space of the three analyzed. Consequently, it will continue to be the best with the presence of green walls. However, in none of the cases, the adequate comfort zone is reached, only the permissible one. The base model and the $20 \%$ green wall model are those that are closest to the comfort zone. Cataloging the $20 \%$ green wall model as the best option for the urban void as it not only helps comfort, but also $\mathrm{CO}_{2}$ emissions, as previously shown.

4. In the case of Street 1 , the most beneficial model for comfort is the $20 \%$ green wall model, since it is the one that is closest to the comfort zone. In this case, the comfort zone is not reached in any of the models and the $\mathrm{CO}_{2}$ values do not improve, however, they are within the permitted ranges. It is important to consider that with other actions surely these models can achieve comfort.

5. On Street 2, the base model, $10 \%$ green wall model, and $20 \%$ green wall model, are in the permissible comfort zone, with green wall being $10 \%$, the model that is closest to the comfort zone.

6. The results obtained in the analysis of the plot of the city of Portoviejo, for the study of the implementation of green walls as a mitigating element of the heat island effect and external comfort, demonstrate that the changes to improve the comfort of the spaces are not significant. Starting from relatively good values (the current state), regarding the comfort of the spaces, improving these values with the implementation of vegetation in the urban fabric is not a representative action. For this reason, these results allow us to question whether the values are real, or whether they are the cause of the margin of error presented by the software based on the calculation engine. 


\section{REFERENCES}

[1] Saidi, K. \& Hammami, S., The impact of $\mathrm{CO}_{2}$ emissions and economic growth on energy consumption in 58 countries. Energy Reports, 1, pp. 62-70, 2015.

[2] Domenech García, A.I., Evaluación comparativa de los principales sistemas de indicadores de sostenibilidad en el ámbito urbanístico. Aplicación práctica al caso de Cartagena, 2012.

[3] Mahdavinejad, M., Zia, A., Larki, A.N., Ghanavati, S. \& Elmi, N., Dilemma of green and pseudo green architecture based on LEED norms in case of developing countries. Int. J. Sustain. Built Environ., 3(2), pp. 235-246, 2014.

[4] Lucius, I., Dan, R. \& Caratas, D., The report was prepared by: Giurgiu County Council, Miruna Dudau, 2011. www.surf-nature.eu. Accessed on: 2 Mar. 2020.

[5] Vásquez, A.E., Infraestructura verde, servicios ecosistémicos y sus aportes para enfrentar el cambio climático en ciudades: el caso del corredor ribereño del río Mapocho en Santiago de Chile. Rev. Geogr. Norte Gd., 63, pp. 63-86, 2016. https://scielo.conicyt.cl/scielo.php?script=sci_arttext\&pid=S0718-340220160001000 05\&lng=es\&nrm=iso\&tlng=es. Accessed on: 26 Jun. 2020.

[6] Fernández-Cañero, R., Pérez, N., Quevedo, S., Pérez, L. \& Franco, A., Ajardinamiento de fachadas y jardines verticales: otras formas de jardinería aplicadas a un desarrollo urbano más sostenible, 2008.

[7] Blanc, P., The Vertical Garden, From Nature to Cities, 2008.

[8] Institute of Physics in Berlin-Adlershof, Urban Ecological Model Projects Bauen, 2002.

[9] Bruse, M., Thönnessen, M. \& Radtke, U., Practical and theoretical investigation of the influence of façade greening on the distribution of heavy metals in urban streets. International Conference on Urban Climatology, Sydney, Australia, 1999.

[10] Dunnett, N. \& Kingsbury, N., Planting Green Roofs and Living Walls, 2004.

[11] Bass, B. \& Baskaran, B., Evaluating rooftop and vertical gardens as an adaptation strategy for urban areas, 2003. http://irc.nrc-cnrc.gc.ca/ircpubs. Accessed on: 26 Jun. 2020.

[12] Schmidt, M., The evapotranspiration of greened roofs and façades. 4th Annual Greening Rooftops for Sustainable Communities, 2006. www.osti.gov/etdeweb/ biblio/20861975. Accessed on: 6 Jun. 2019.

[13] Fariña Tojo, J., Fernández Áñez, M.V., Galvez Huerta, M.A., Hernández Aja, A. \& Urrutia del Campo, N., Manual de diseño bioclimatico urbano. Recomendaciones para la elaboracion de normativas urbanistica, 2013.

[14] Correa, E.N., Flores Larsen, S. \& Lesino, G., Isla de calor urbana: Efecto de los pavimentos. Informe de avance, 2003.

[15] De Schiller, S., Evans, J.M. \& Katzchener, L., Isla De Calor, Microclima urbano y variables de diseño estudios en Buenos Aires y Rio Gallegos. Av en Energías Renov y Medio Ambient, 2001. www.cricyt.edu.ar/asades/modulos/averma/trabajos/2001/ 2001-t001-a009.pdf.

[16] Nogueira, G., Certificaciones de Urbanismo: Análisis comparativo y transversal de los programas de certificación con criterios de sostenibilidad, 2000.

[17] Bruse, M., Thönnessen, M. \& Radtke, U., Practical and theoretical investigation of the influence of façade greening on the distribution of heavy metals in urban streets. International Conference on Urban Climatology, Sydney, Australia, 1999.

[18] Alcazar, S., Efectos de las cubiertas ajardinadas sobre el microclima urbano en verano. Tesis Dr., 2015. 
[19] ENVI_MET, ENVI_MET, 2019. www.envi-met.com/intro/. Accessed on: 27 Mar. 2019.

[20] Tumini, I. \& Pérez Fargallo, A., Del Confort Térmico En Espacios Abiertos, En Madrid. Habitat Sustentable, 5, pp. 57-67, 2015.

[21] González, L.E.Q. \& González, J.R.Q., Living green infrastructures: Typological characteristics, benefits and implementation. Cuad Vivienda y Urban, 12(23), 2019. 